\title{
Yahudilikte İtikâdî Bir Sapkınlık Türü Olarak Apikoros
}

\author{
Apikoros as a Kind of Heresy in Judaism
}

\section{Rumeysa Bektaş}

Arş. Gör., Afyon Kocatepe Üniversitesi İslami İlimler Fakültesi

rrumeysabektas@gmail.com \& https://orcid.org/oooo-0001-7683-7729

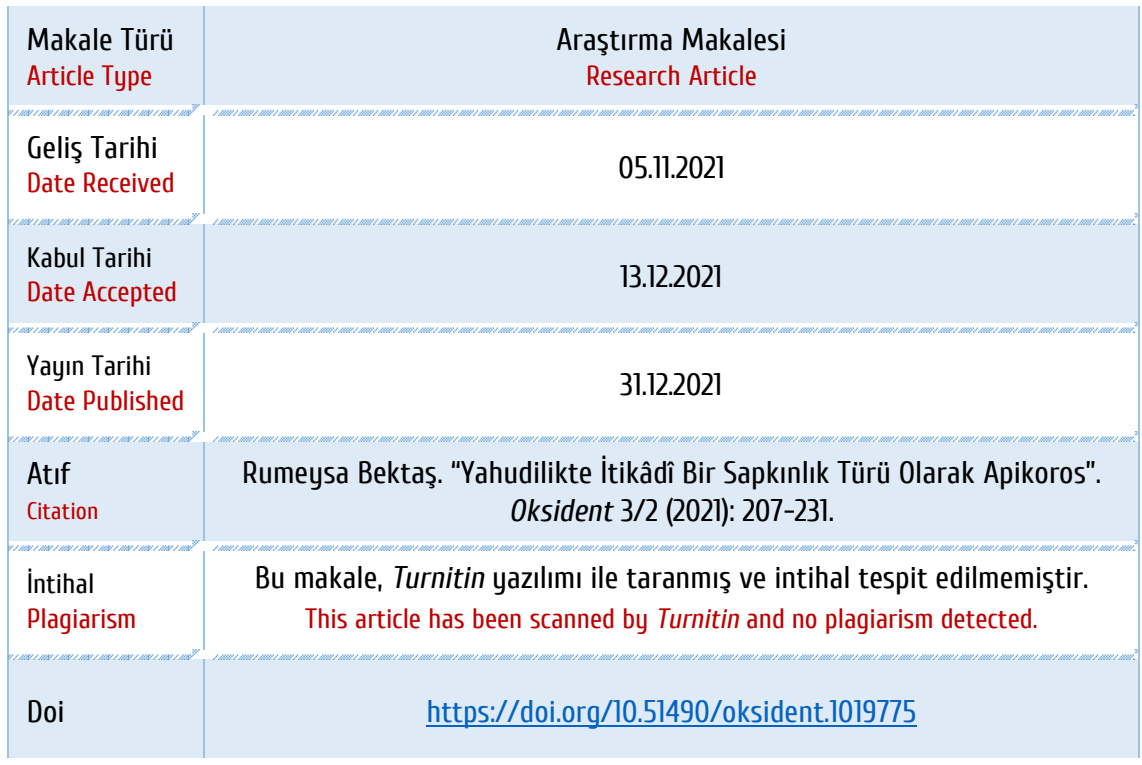


Öz

İtikâdî açıdan sapkın kabul edilen kimseler, Yahudi dinî literatüründe çeșitli terimlerle isimlendirilmiştir. Başta İbn Meymun (ö. 1204) olmak üzere Yahudi âlimler, sapkın kimseleri sapkınlı türlerine göre kategorize etmişlerdir. Sonraki süreçte ise benzer düşünce ve dauranışa sahip Yahudileri de aynı kategoriye dâhil ederek Tanri'nın sapkınlara vereceği cezaları bildirmek suretiyle onları uyarmışlardır. Yahudi dinî literatüründe itikâdî açıdan sapkin kimseler için kullanılan yaygın kauramlardan bir tanesi de apikorostur. Yunan filozof Epikür'den (ö. MÖ. 270) türeyen apikoros sözcüğü, özel bir isimken ilerleyen süreçte inançsiz veya inancinda kusurlu kimseleri ifade eden bir tür ismine dönüşmüştür. Yahudiliğin temel inanç esaslarıyla çelişen düşüncelere sahip olan apikoroslar, Yahudi din adamlarmin cephe aldığı bir grup haline gelmiştir. Yahudileri doğru yoldan çıkardıkları gerekçesiyle Yahudi dinî literatüründe apikoroslarla nasl mücadele edileceği gibi birçok husus ele alınmıştır. Bu çalışmada apikoros kauramının kökeni, apikorosların düşünce yapiları, Yahudiler üzerindeki etkileri, Yahudi toplumundaki konumlar, ahirette alacakları cezalar gibi çeşitli hususlar ele alınmıștır.

Anahtar Kelimeler: Yahudilik, İtikâdî Sapkınlık, Epikür, Apikoros, Kâfir, Mülhid.
Abstract

People considered heretical in faith were named by various terms in Jewish literature. Jewish scholars, especially Maimonides (d. 1204), categorized heretics according to the kind of heresy. Later, they included Jews who had similar thoughts and behaviors in the same category and warned them about God's punishments for heretics. One of the standard terms used in Jewish literature for heretics is apikoros. The term apikoros was derived from the Greek philosopher Epicurus (d. 270 BC). Although it was a proper name at first, it gradually turned into a common name denoting people who were unbelievers or imperfect in their faith. Having thoughts that contradicted the basic principles of the Jewish faith, the apikorsim became a group against which the Jewish clergy sided. Because of the fact that they misled Jews from the right path, many discussions arose in Jewish literature, such as how to struggle apikoros. This article discusses the origin of the term of the apikoros, the mindset of the apikoros, their effects on the Jews, their position in the Jewish society, and the punishments they will receive in the hereafter.

Keywords: Judaism, Heresy, Epicurus, Apikoros, Kafir, Mulhid. 


\section{Özet}

Birçok dinde olduğu gibi Yahudilikte de dinin inanç esaslarına aykırı düşünce ve davranışlarda bulunanlar itikâdî açıdan sapkın ilan edilmiştir. Sapkınlık türleri kategorize edilmiş, sapkın kişiler bu kategoriler bağlamında farklı şekillerde adlandırılmıştır. Yahudi dinî literatüründe yer alan sapkınlık terimleri arasında öne çıkanlardan biri de apikorostur. Apikoros kelimesinin kökeni bağlamında farklı iddialar ortaya atılmıştır. Kelimeyi Yunanca bir kökenle ilişkilendirenlere göre apikoros sözcüğü Yunan filozof Epikür'e dayanmaktadır.

Epikür, hazzı hayatın merkezine alan, materyalist bir bakış açısına sahip olan; diriliş, cennet, cehennem ve ahiret gibi kavramların hayatta yeri olmadığını öne süren bir filozoftur. Hatta o, bazı yorumcular tarafından, günümüz deizm ve ateizm akımlarının öncüsü kabul edilmiştir. Epikür'ün düşünceleri büyük kitlelere ulaşmış, çok sayıda insan onun fikirlerini benimsemiştir. Epikür'ün düşünce sistemi etrafında şekillenen bir akım ortaya çıkmış ve bu akım Epikürcülük olarak isimlendirilmiştir. Zamanla Yahudiler ve Hıristiyanlar arasında da etki alanı bulan Epikürcülük, Helenistik dönemin en önemli felsefi ekollerinden biri haline gelmiştir. Yahudiliğin temel inanç esaslarıyla çelişen öğretilere sahip olmasindan ötürü Epikür'ün düşüncelerini savunanlar, Yahudi din adamları tarafindan sapkın ilan edilmiştir. Popüler hale gelen Epikürcülük, Yahudilerden bir kısmının da inancını sorgular hale gelmesine zemin hazırlamıştır. Helenistik dönemin başlarında Epikür ve Epikürcülükle tanışan Yahudilerin bu dönemde kaleme aldıkları metinlerinde de Epikürcülüğün izleri görülmektedir. Epikür'ün görüşlerinden etkilenen Yahudiler, apikoros olarak adlandırılmış ve dindar Yahudiler bu kimselere karşı ikaz edilmiştir.

\section{Summary}

People who think or act contrary to the principles of faith are declared heretics in Judaism as in many religions. Kinds of heresy were categorized, and heretics were named in different ways within the context of these categories. One of the prominent terms of heresy in Jewish literature is apikoros. Various claims have been put forward in the origin of the word apikoros. According to those who associate the word with a Greek origin, apikoros dates back to the Greek philosopher Epicurus.

Epicurus is a philosopher who puts pleasure at the center of life, has a materialistic point of view, and argues that concepts such as resurrection, heaven, hell, and the hereafter have no place in life. Some commentators accepted him as the pioneer of today's deism and atheism movements. Epicurus' ideas reached large masses, and many people adopted his ideas. A movement shaped around Epicurus' thought system emerged, and this movement was named Epicureanism. Epicureanism, which influenced Jews and Christians in time, became one of the most important philosophical schools of the Hellenistic period. The Jewish clergy declared the proponents of Epicurean ideas heretic because of having teachings that contradict the fundamental beliefs of Judaism. Epicureanism, which became popular, caused some Jews to question their faith. At the beginning of the Hellenistic period, the effect of Epicureanism could be seen in the texts of the Jews. Jews influenced by the views of Epicurus were called apikoros, and religious Jews were warned against him.

Jewish scholars who wanted to find an origin for the word in their language, associated apikoros with the 
Kelimeye kendi dillerinden bir köken bulma ihtiyacı hisseden Yahudi âlimler, הפקר apikorosu "sahipsiz" anlamındaki (hefker) kelimesiyle ilişkilendirmişlerdir. $\mathrm{Bu}$ bağlamda apikoros, Tevrat'ı küçük gören, dünyaya sahipsiz muamelesi yapan, dolayısıyla da dinî kurallara riayet etmeyerek kendisi de sahipsiz kalan anlamında kullanılmıştır. Terim, Aramice "saygisızlık" anlamina gelen אפקירותא (afkiruta) sözcüğüyle de ilişkilendirilmiştir. Bu bağlamda, Tevrat'a ve Yahudi din adamlarına saygısızlık edenler ve onların sadece kendi çıkarları için Tevrat öğrendiklerini iddia edenler apikoros addedilmiştir.

Yahudi dinî literatüründe de apikoros terimine yer verildiği görülmektedir. Mişna, Talmud, Tosefta gibi temel Yahudi dinî kaynaklarının yanı sıra Orta Çağ Yahudi âlimlerinin eserlerinde de apikorosa dair bilgiler mevcuttur. $\mathrm{Bu}$ kaynaklarda apikorosun kimliği, hangi düşüncelere sahip olduğu, ona nasıl muamele edilmesi gerektiği ve öldükten sonra nasıl bir cezaya maruz kalacağ gibi birçok hususa değinilmiştir. Apikorosların dinin temel inançlarını inkâr eden, din adamlarına saygisızca davranan sapkın insanlar oldukları ve gelecek dünyadan nasiplerinin olmayacağı belirtilmiştir. İbn Meymun'dur (ö. 1204) bu sapkınlık türünü kapsamlı bir şekilde ele almıştır. O, on üç maddelik Yahudi iman esasları listesi hazırlamış ve bu iman esaslarından birini dahi inkâr eden kişinin Yahudi cemaatinden dışlanacağını belirtmiştir. İbn Meymun'un aktardığı inkârcılar listesinde apikoros da bulunmaktadır. İbn Meymun, üç çeşit insanın apikoros olduğunu söylemiştir. Ona göre; nübüvveti ve vahyi inkâr eden, Musa'nın peygamber olduğuna inanmayan ve Tanrı'nın insanların yaptıklarından haberdar olmadığını söyleyen kişiler apikorostur. Bunların yanında Mişna şerhlerinde de apikorosun kim olduğu ve akıbetinin nasıl olacağına dair çeşitli word (hefker), meaning unclaimed. In this context, apikoros means the one who despises the Torah, treats the world as unclaimed, and therefore does not obey the religious rules and becomes unclaimed himself. The term is also associated with the Aramaic word אפקירותא (afkiruta), meaning disrespect. In this context, those who disrespect the Torah and the Jewish clergy, claiming that they learned the Torah only for their benefit, were considered apikoros.

The term apikoros is seen to have been used in Jewish literature. In addition to fundamental religious sources such as the Mishnah, Talmud, and Tosefta, there is also information about apikoros in the works of medieval Jewish scholars. In these sources, many issues were addressed, like the identity of the apikoros, his thoughts, the way he should be treated, and the kind of punishment after death. The apikorsim are identified as heretics who deny the fundamental beliefs of religion, treat the clergy with disrespect, and will not achieve anything in the hereafter. Maimonides (d. 1204) dealt with this kind of heresy comprehensively. He prepared a thirteen-point list of Jewish principles of faith and stated that anyone who denies even one of these principles of faith will be excluded from the Jewish community. Apikoros was also included in the list of deniers cited by Maimonides. He said that three kinds of people are apikoros. Accordingly, apikoros is a person who denies prophecy/revelation in general or Moses' prophethood or says that God is unaware of what humans are doing. Moreover, various explanations and interpretations were made in the commentaries of the Mishnah about the identity of the apikoros and his fate. In these commentary texts written by Jewish scholars, apikoros was 
açıklama ve yorumlar yapılmıştır. Yahudi âlimlerin kaleminden çıkan bu şerh metinlerinde apikoros teriminin zaman zaman bazı sapkın grupları nitelemek için kullanıldığı da görülmektedir.
Apikoroslar alt başlıklara ayrılmaktadır. Goy apikoroslar olabileceği gibi Yahudi apikoroslar da olabilir. Muamelat hususunda goy apikoroslara ve Yahudi apikoroslara farklı şekilde yaklaşılır. Yahudi apikoroslar hakikati bildikleri halde doğru yoldan saptıkları için daha tehlikeli görülürler. Öte yandan, Babil Talmudu'ndaki "Yahudi, günah işlese de yine Yahudi'dir" ifadesi esas alınarak Yahudi apikorosların günahkâr oldukları, ancak Yahudilik bünyesinde kalmaya devam ettiklerine dair yorumlar da mevcuttur. Ayrıca kişinin apikoros olma sebepleri de bilinmeli ve buna göre bir ayrım yapılmalıdır. Kişi özgürce hareket etme isteğiyle, Yahudi toplumunu yok etme düşüncesiyle, entelektüel sebeplerle veya baskıyla inkârcı olmuş olabilir. Bütün bu ayrımlar, apikoroslara muamelat konusunda bilinmesi gereken unsurlardandir.

Sapkın olarak görülen apikoroslar Yahudi toplumunda dinî, hukuki ve sosyal açıdan çeşitli olumsuz yaklaşım ve yaptırımlara maruz kalırlar. Apikorosları öldürmek bir mitsvadır. Öldürmek mümkün değilse ölümüne yol açacak bir plan yapılmalıdır. Onların şahitlikleri kabul edilmez, sözlerine güvenilmez. Yahudiler, apikorosun kayıp bir eşyasını bulurlarsa, eşyayı kendisine iade etmemeleri gerekir. Bir apikorosun yazdığı Tevrat tomarı yakılmalıdır. Apikorosun kestiği bir hayvanın etinden yemek caiz görülmemiştir. Yaşadıkları süre zarfında her alanda kötü muameleye maruz kalan apikorosların ölmesi durumunda ise yakınları yas tutmak yerine kutlama yaparlar.

Apikoros sözcügüu, İbranice ve Aramice kökenle ilişkilendirilmeye çalışılsa da genel kanaate göre Yunan filozof Epikür'le sometimes used to describe some heretic groups.

Apikoros is divided into subheadings, such as goy apikoros and Jewish apikoros. They are treated differently. Jewish apikoros is seen as more dangerous than the other because he strayed from the right path even though he knew the truth. On the other hand, based on the statement "A Jew is still a Jew even if he sinned" in the Babylonian Talmud, Jewish apikoros was thought to remain within Judaism although he was sinful in some interpretations. In addition, the reasons for the person to be apikoros should be known, and a distinction should be made accordingly. The person may have been a denier with a desire to act freely, with the thought of destroying the Jewish community for intellectual reasons or by oppression. All these distinctions are essential elements in the treatment of apikoros.

Apikoros, seen as a heretic, is exposed to various negative approaches and sanctions in the Jewish community's religious, legal, and social aspects. Killing apikoros is a mitzvah. If it is impossible to kill, a plan must be made to lead to his death eventually. His testimonies are not accepted, and his words cannot be trusted. If the Jews find a lost item of an apikoros, they should not return it to him. The Torah scroll written by an apikoros must be burned. The meat of an animal slaughtered by an apikoros is not permissible to eat. Apikoros is mistreated in all areas during his lifetime. When an apikoros dies, his relatives celebrate the event instead of mourning.

Although the word apikoros is tried to be associated with Hebrew and Aramaic origins, it is generally related to the Greek philosopher Epicurus. Epicureanism influenced both the 
bağlantılıdır. Epikür'ün felsefi düşüncelerinin yayılmasıyla birlikte Epikürcülük, gerek goyları gerekse de Yahudileri etkilemiştir. Apikoros, Epikürcü görüşleri benimseyenleri ifade etmek için kullanılan bir sözcükken geleneksel Yahudi düşüncesine göre sapkın oldukları iddia edilen kişileri ifade eden bir çatı kavram olmuştur. Yahudi dinî literatüründe tanımlanan apikoros, gelecek dünyadan nasibi olmayan gruplar arasında zikredilmiştir. Apikoroslar, bir tehdit olarak görülmüş, hukuki ve sosyal haklarından mahrum birakılarak Yahudi toplumundan dışlanmış ve Yahudiler apikoroslara karşı uyarılmıştır. goyim and the Jews with the spread of Epicurus' philosophical ideas. While apikoros had been a word used to express those who adopt Epicurean views, it became a common name representing people claimed to be heretics according to traditional Jewish thought. As defined in Jewish literature, apikoros is mentioned among groups that have no share in the world to come. Because he is seen as a threat, the apikoros is removed from the Jewish community, deprived of their legal and social rights, and Jews are warned against him. 


\section{Giriş*}

Din, insan topluluklarının merkezinde yer alan, teorik ve pratik boyutları olan inanç sistemidir. Her dinin kutsal kabul ettiği unsurlar vardır. Dinî otoriteler, kutsal sayılan unsurlara saygıyla yaklaşılması, dinî emirlerin yerine getirilip yasaklardan uzak durulması, dolayısıyla inancın Tanrı'nın arzuladığı şekliyle hayata dökülmesi misyonunu üstlenmişlerdir. Bu nedenle herhangi bir dine mensup olan insanların, o dinin kutsallarına gereken saygıyı göstermemeleri, dinin emir ve yasaklarına riayet etmemeleri sonucunda dinî otoriteler, ilk aşamada bu kimseleri uyarmakta, uyarıların dikkate alınmaması durumunda ise önceden haber verilen uhrevî cezalara ek olarak dünyevî cezaları bizzat takdir eden merci olmaktadırlar. Dünyevî ve uhrevî cezası olan büyük günahlardan biri de itikâdî sapkınlıktır. Yüzylllar boyunca birçok dinin içerisinde çeşitli formlarda zuhur eden bu sapkınlıklar, zaman zaman günahkâr addedilen kimsenin cemaatten uzaklaştırılması yahut tamamen kovulması ile neticelenmiştir.

Yahudilikte sapkınlık, en yalın ifadeyle, Tanrı'nın Hz. Musa'ya bildirdiği ilahi emirlere riayet etmemek anlamında kullanılmıştır. Ancak zamanla sapkınlık kavramının içeriği de değişmiş ve genişlemiştir. Putperestlik âdetlerini devam ettirenler ve şeriatın yasakladığı işleri yapanlar, Tanrı katında "kötü olanı yapanlar (osim ha-ra')" olarak tanımlanmıştır. Ayrıca sapkın kimselerin sapkınlıklarının onları felakete sürükleyeceği vurgulanmıştır. ${ }^{2}$ Bu kimseleri tanımlamak için Tanah'ta; "Tanrı'yı unutanlar (şohohey el)"3, "dinsiz (hanef)"4 ve "sefih (evîl)" gibi sözcükler de yer almaktadır. ${ }^{6}$

Bu makale, 2020 yılında Ankara Ü. Sosyal Bilimler Enstitüsü'nde tamamlanan "Yahudilikte İtikâdî Sapkınlıklar ve Cezaları" başlıklı yüksek lisans tezinden üretilmiştir.

$1 \quad$ Yasa'nın Tekrarı 4:25, 9:18, 31:29; Hâkimler 2:11, 3:7, 3:12, 4:1, 6:1, 10:6, 13:1; I. Samuel 15:19; I. Krallar 11:6, 14:22, 15:34, 16:25, 16:30, 21:20, 21:25, 22:52; II. Krallar 3:2, 8:18, 8:27, 13:2, 13:11, 14:24, 15:9, 15:18, 15:24, 15:28, 17:2 17:17, 21:2, 21:15, 21:16, 21:20, 23:32, 23:37, 24:9, 24:19; II. Tarihler 21:6, 22:4, 29:6, 33:2, 33:22, 36:5, 36:9, 36:12; Nehemya 9:28; Mezmurlar 51:4; Yeşaya 65:12, 66:4; Yeremya 7:30, 18:10, 32:30, 52:2.

Süleyman'ın Meselleri 11:2.

Eyüp 8:13.

Eyüp 8:13, 13:16; Süleyman'ın Meselleri 11:9. Hanef kavramı için bkz. Marcus Jastrow, "Hanef", Dictionary of Targumim, Talmud and Midrashic Literature (Londra: Luzac \& Co., 1926), 485; Fuat Aydın, Kur'an'daki Hanîf/ler ve Nasârâ Üzerine Araştırmalar (Ankara: Eskiyeni Yayınları, 2016).

5 Eyüp 5:3.

6 Ömer Faruk Harman, "Dalâlet”, Türkiye Diyanet Vakfi İslam Ansiklopedisi (Ankara: TDV Yayınları, 1993), 8: 4,27. 
Yahudilikte itikâdî sapkınlığı ifade eden birçok sözcük kullanılmaktadır. Bu sözcüklerin çoğu Mişna'da bulunmakta ve itikâdî açıdan sapkın addedilenler, "gelecek dünyadan nasibi olmayacak kimseler" kategorisinde yer almaktadır. Bahsi geçen ifade şöyledir:

Bütün Yahudilerin gelecek dünyadan nasibi vardır. Yeşaya, 60:21'de denildiği gibi, "Halkımın hepsi doğru kişiler olacak. El emeğim, görkemimi göstermek için diktiğim fidan, ülkeyi sonsuza dek mülk edinecek." Gelecek dünyadan nasibi olmayacak kişiler ise şunlardır: Tevrat'ta dirilişe dair bir ifade yoktur diyenler, Tevrat vahiy mahsulü değildir diyenler ve apikoroslar. Rabbi Akiba (şu kimselerin de gelecek dünyadan nasibi olmayacağını) söyledi: "Kanonik olmayan kitaplar (sfarim ha-hitsonim) okuyanlar ve "Mısırlılara verdiğim hastalıkların hiçbirini size vermeyeceğim, çünkü size şifa veren Rab benim" (Çıkış, 15:26) cümlesini okuyarak (sihir/büyüyle) yaraya fısıldayanlar (loheş al ha-make)." Abba Şaul dedi ki: “Tanrı'nın ilahi adını hecelendiği gibi telaffuz eden kişi (hoge et ha-şem be-otiyotav) de (bu gruptadır)." Üç kral ve halktan dört kişinin gelecek dünyadan nasibi yoktur. Üç kral; Yeroboam, ${ }^{7}$ Ahab ${ }^{8}$ ve Menaşe'dir... ${ }^{9}$ Tufan ehlinin gelecek dünyadan nasibi yoktur... Sodom halkının gelecek dünyadan nasibi yoktur... Casusların ${ }^{10}$ gelecek dünyadan nasibi yoktur... Çöldeki neslin ${ }^{11}$ gelecek dünyadan nasibi yoktur... (Yere batırılan) Karun'un topluluğu (tekrar yerden) çıkarılmayacaktır... Putperest bir şehrin sakinlerinin gelecek dünyadan nasibi yoktur... ${ }^{12}$

Yukarıda verdiğimiz Mişna tercümesi sapkınlık türleriyle ilgili en fazla alıntılanan metindir. Bu metin başta olmak üzere Yahudi dinî literatürü bir bütün olarak incelendiğinde Yahudilikte sapkınları ifade

7 I. Krallar 13.

$8 \quad$ I. Krallar 16:30.

9 II. Krallar 21.

10 Casuslardan kasıt, Hz. Musa'nın Kenan ülkesini keşif için gönderdiği 12 casustan 10'udur. Yefunne b. Kalev ve Yeşu b. Nun dışındaki bütün casuslar Kenan topraklarında çok güçlü insanların yaşadığını ve onlarla savaşamayacaklarını söyleyerek İsrailoğullarının cesaretini kırmışlardır. Bkz. Çölde Sayım 13. Bölüm.

11 Burada kastedilen, Mısır'dan çıktıktan sonra çöldeyken Musa'ya itaat etmeyen ve altın buzağıya tapan İsrailoğullarıdır. Bkz. Çıkış 32. Bölüm. Altın buzağıyla ilgili bkz. Yasin Meral, Sâmirî’nin Buzağısı, 2. bs. (Ankara: Ankara Okulu Yayınları, 2021).

12 Mişna, Sanhedrin, 10:1-6. 
etmek için kullanılan sözcükler; apikoros, hitsonim, ${ }^{13}$ kofer, ${ }^{14}$ kotsets beneti'ot, ${ }^{15}$ meşumad, ${ }^{16}$ min, ${ }^{17}$ mumar, ${ }^{18}$ poreş mi-darhey tsibur, ${ }^{19}$ poş'ey Yisrael ${ }^{20}$ ve zaken mamre ${ }^{21}$ dir. ${ }^{22} \mathrm{Bu}$ kavramlar arasında apikoros, dinî literatürde kendisine geniş yer verilmesi bakımından öne çıkan bir sapkınlık türüdür.

13 Kelime anlamı "dışarıdakiler, yabancılar" olan hitsonim, itikâdî açıdan sapkınlık sayılan sözler söyleyen veya sapkın davranışlarda bulunan kişileri ifade etmektedir. Hitsonim, geleneksel Yahudi düşüncesinin dışında kalanları belirten çatı bir kavramdır. Bkz. Hannah Kasher, Al ha-Minim, ha-Apikorsim ve ha-Koferim ba-Mişnat ha-Rambam (Tel Aviv: Hakibbutz Hameuchad Publishing House, 2011), 52.

14 Kelime anlamı "inkâr etmek" olan kafar fiilinden türeyen kofer, "inkârcı" demektir. Kofer, yalnızca dinî bir inkârı ifade etmez, genel olarak herhangi bir şeyi inkâr etmeyi ifade eden bir sözcüktür. İnkâr edilen şeye göre kofer sözcüğü ek alabilmektedir. Mesela, inanç esaslarından birini inkâr eden kofer ba-'ikkar olarak isimlendirilirken Tevrat'ı inkâr eden kişi kofer ba-Tora şeklinde isimlendirilmiştir. Bkz. Babil Talmudu, Sanhedrin, 39a-b; Yosef Albo, Sefer ha-'ikkarim (Philadelphia: The Jewish Publication Society of America, 1946), 1:5, 2:8, 13:3-4; 2, 6:4.

15 "Bitki koparan" anlamına gelir. Talmud'da Elişa ben Abuya (MS. 1. yy.) için kullanılmıştır. Kotsets be-neti'ot'un ayırt edici özelliği; diğer terimler gibi bir grubu ifade etmekten ziyade hassaten Elişa ben Abuya ile özdeşleşen bir kavram olmasıdır. Bkz. Babil Talmudu, Hagiga, 14b-15a.

16 Dinden dönmeyi ifade eder. Başta sadece baskı sebebiyle dinlerinden dönenleri ifade eden bir kavramken zamanla kelimenin kapsamı genişlemiş ve her çeşit irtidatı ifade eden bir kavrama dönüşmüştür. Bkz. Jastrow, Dictionary of Targumim, Talmud and Midrashic Literature, 850, 1592.

17 Kelime anlamı "tür"dür. Bazen cins isim, bazen de özel isim olarak kullanıldığı görülmektedir. Cins isim olarak kullanıldığında dinî cemaatten ayrılan Yahudileri karşılarken özelde ise geçmişten günümüze çok sayıda sapkın grup için kullanılmıştır. Bkz. Daniel Spercer, “Min”, Encyclopedia Judaica, Second Edition, ed. Fred Skolnik (Detroit: Macmillan Reference, 2007), 14: 263-264.

18 Dinden dönmeyi ifade eden mumar, meşumad ile eş anlamlıdır. Yahudi dinî literatürü incelendiğinde birçok bölümde mumar ve meşumad sözcüklerinin birbirlerinin yerine kullanıldığ görülmektedir. Fakat mumar, daha az pejoratif sayılan bir kavramdır. Meşumad, İslam literatüründeki mürtedi ifade ederken mumar, mühtedi anlamı taşır, şeklinde bir karşllaştırma yapılabilir. Bkz. David M. Grossberg, Heresy and the Formation of the Rabbinic Community (Tübingen: Mohr Siebeck, 2017), 118.

19 "Toplumun geleneklerinden sapan" Yahudileri ifade eden bir terimdir. Bu Yahudilerin günahları nedeniyle sapkın sayıldıkları ve gelecek dünyada cezalarını çekecekleri belirtilmiştir. Babil Talmudu, Roş ha-Şana, 17a.

20 "İsrail'in günahkârı" anlamına gelmektedir ve günahkâr Yahudileri ifade eden çatı bir kavramdır. Bkz. Grossberg, Heresy and the Formation of the Rabbinic Community, 92-98.

$21 \quad$ Kelime anlamı "isyankâr ihtiyar" olan zaken mamre, Yahudi mahkemesi Beyt Din'in kararına bilinçli olarak karşı çıkan hâkime verilen isimdir. Zaken mamre, toplumu dalalete sürüklediği gerekçesiyle uyarılmış, hatasında ısrarcı olması durumunda ise ölüm cezası verilmiştir. Bkz. Abraham Arzi, “Zaken Mamre”, Encyclopedia Judaica (Detroit: Macmillan Reference, 2007), 21: 446.

22 Kavramlarla ilgili ayrıntılı bilgi için bkz. Rumeysa Bektaş, Yahudilikte İtikâdî Sapkınlıklar ve Cezaları (Yüksek Lisans Tezi, Ankara: Ankara Üniversitesi, 2020). 
$\mathrm{Bu}$ terimin en önemli niteliklerinden biri de felsefi boyutunun olmasıdır. Çünkü apikoros kavramı, Yunan filozof Epikür'le (ö. MÖ. 270) ilişkilendirilmektedir. Çalışmamızda Yahudilik bünyesinde sapkınlık için kullanılan temel kavramlardan biri olan apikoros terimi açılanacak ve irdelenecektir. Bu doğrultuda apikoros teriminin etimolojisi, apikorosların düşünce ve davranışları, terimin Yahudi dinî literatüründe kullanımı ve Yahudilikte apikorosların hukuki durumu konu edilecektir.

\section{1) Apikoros Kavramının Etimolojisi}

Apikoros (אפיקורוס) sözcüğünün etimolojisine dair farklı iddialar bulunmaktadır. Terimin kökenini Yunancayla ilişkilendiren yaklaşıma göre apikoros, Epíkouros kelimesinden türetilmiştir ve Helenistik felsefenin önemli temsilcilerinden biri olan Yunan filozof Epikür'ün takipçilerini ifade etmektedir. ${ }^{24} \mathrm{Bu}$ bağlamda apikoros, Epikür'ün Yahudi dinî düşüncesine aykırı görüşlere sahip olması sebebiyle, olumsuz bir anlam taşımaktadır.

Yahudilikte bir sapkınlık türü olan apikoros teriminin Yunan filozof Epikür'le ilişkilendirilmesi Epikür'ün ve Epikürcülüğün iyi anlaşılmasını gerektirmektedir. "Felsefe, mutlu bir yaşam sağlamak için tutarlı eylemsel bir sistemdir, evrende her şey insan için haz objesidir. Ancak erdemle gelen bilgi arttıkça haz da artar. Bu nedenle yönelim hazza değil bilgiye olmalıdır, zevk mutlu bir yaşamın başlangıcı ve amacıdır. Bilginin amacı; insanı bilgisizlik ve boş inançlardan, tanrı ve ölüm korkusundan kurtarmaktır. Ve bu olmadan mutlu olmaya imkân yoktur, ölümden korkmak anlamsızdır, çünkü yaşadığımız sürece ölüm yoktur, ölüm geldiğinde ise artık biz yokuz"25 şeklinde sözler söyleyen Epikür, materyalist ve hedonist ${ }^{26}$ olmakla

23 Apikoros kelimesinin yazımında bazı farklılıklar tespit edilmiştir. Kelime, Mişna metnini düzenleyen editörler tarafından bazen apikoros, bazen epikoros, bazen de epikores şeklinde harekelenmektedir. Epikoros ve epikores şeklinde harekelendirenlerin, kelimenin kökenini doğrudan Yunan filozof Epikür'le ilişkilendirdikleri söylenebilir. Ancak kelimenin yaygın kullanımı apikoros olduğu için, çalışmamızda apikoros yazımı esas alınmıştır.

24 Gotthard Deutsch, "Apikoros", The Jewish Encyclopedia (New York: Funk and Wagnalls, 1901), 1: 665; Philip Birnbaum, Encyclopedia of Jewish Concepts (New York: Hebrew Publishing Company, 1998), 56.

25 Macit Gökberk, Felsefe Tarihi (İstanbul: Remzi Kitabevi, 1985), 99; Dan Cohn-Sherbok, “Apikoros”, A Concise Encyclopedia of Judaism (Londra: One World Publications, 1998), 31.

26 Hedonizm veya Hazcılığa göre haz, insan için en iyi olandır ve insanlar, hayatlarının merkezine hazzı almalıdır. 
suçlanmıştır. ${ }^{27}$ Epikür, öldükten sonra dirilmeyi reddetmesinin yanı sıra Tanrı ve nübüvvet kavramları hakkındaki görüşleri sebebiyle Rabbani otoriteler tarafından sapkın olarak görülmüştür. Epikür'ün atomcu teorisi, ${ }^{28}$ adalet kavramını dinî kâidelerin üzerinde tutması, ibadetlere gerek olmadığı, hayatın gayesinin zevke ve mutluluğa ulaşmak olduğu ve ölümün tamamen bir yok oluş olduğu yönündeki görüşleri; kısacası din ve ahiretle ilgili bütün olgu ve inançları reddetmesi ${ }^{29}$ nedeniyle o ve takipçileri Yahudiler tarafından "inançsız" ve "kâfï" gibi sıfatlarla anılmışlardır. Filozof Lucretius (ö. MÖ. 55), Epikür'ün din yerine bilim ve ahlakı esas aldığını, dolayısıyla ateist ${ }^{30}$ dünya görüşüne sahip ilk filozof olduğunu iddia etmiştir. Epikür, bir yandan ateist olmakla itham edilirken diğer yandan da deizmi savunmakla suçlanmıştır. Bu noktada onun; dünyanın bir yöneticisi olmadığı şeklindeki görüşüyle "ateist”, dünyaya müdahil olan bir Tanrı'nın var olmadığını söyleyerek insanların bütün ibadet ve dinî yükümlülüklerden muaf oldukları fikrini savunmasıyla da "deist" olduğu iddia edilmiştir. ${ }^{31}$

Yaşadığı dönemde ve ölümünden sonra Epikür'ün düşüncelerini destekleyen, hatta benimseyen birçok insan olmuştur. Böylece Epikür'ün görüşleri etrafında şekillenen bir ekol oluşmuş ve bu ekol Epikürcülük adıyla felsefe tarihinde yerini almıştır. Epikürcülük başta Yahudiler ve Hıristiyanlar olmak üzere birçok dinî grup üzerinde de etkisini göstermiştir. Bu felsefi ekol, Platonculuk ve Aristoculuğun yanı sıra Helenistik dönemde öne çıkan üç felsefi ekolden biri olmuştur. Roma'nın en gözde felsefesi haline gelmesi ise Cicero (ö. MÖ. 43) döneminde gerçekleşmiştir. ${ }^{32}$

Epikür'ün ölümünden sonraki asırlarda dinî bakış açısına muhalefet olarak ortaya çıkan birçok sorgulayıcı ve eleştirel akımın ardında Epikür ve

$27 \quad$ Henry Albert Fischel, “Epicureanism”, Encyclopedia Judaica, Second Edition, ed. Fred Skolnik (Detroit: Macmillan Reference, 2007), 6: 463.

28 Epikür'ün atomcu teorisine göre dünya bir yaratıcıya ihtiyaç duymadan kendi kendine var olmuş ve işlemektedir. Yaakov Malkin, Epicurus \& Apikorsim (Kudüs: The Library of Secular Judaism, 2007), 13, 27; Norman Solomon, “Apikoros”, Historical Dictionary of Judaism (Londra: Rowman \& Littlefield, 2015).

29 Malkin, Epicurus \& Apikorsim, 15, 30-31.

30 Epikür'ün ateist olmakla itham edildiği kaynaklar vardır. Bkz. M. Rosenthal, P. Yudin, "Epikuros”, Materyalist Felsefe Sözlüğü, çev. Aziz Çalışlar (İstanbul: Sosyal Yayınlar, 1977), 139; Hayri Bolay, "Epikürizm”, Felsefi Doktrinler Sözlüğü (İstanbul: Ötüken, 1981), 97. Bazı İbranice sözlüklerde de apikoros, ateist olarak tanımlanmaktadır. Bkz. Ernest Klein, A Comprehensive Etymological Dictionary of the Hebrew Language for Readers of English (Kudüs: Carta, 1987), 47.

$31 \quad$ Malkin, Epicurus \& Apikorsim, 31-32.

32 Abdülbaki Güçlü v.dğr., "Epikurosçuluk”, Felsefe Sözlüğü (Ankara: Bilim ve Sanat, 2003), 473. 
Epikürcü ekolün etkili olduğu öne sürülmüştür. Buna örnek olarak Aydınlanma Çağı, Rönesans ve Haskala Hareketi verilebilir. Ayrıca günümüz Avrupa ve ABD'sinde agnostik, deist ve ateist düşüncelerin açığa çıkıp popülerleşmesinin temelinde de yine Epikürcü ekolün olduğuna dair iddialar mevcuttur. Öte yandan Epikürcülük, sekülerleşme sürecine de katkı sağlamış, Yahudi apikorosların, “seküler Yahudiler” olarak adlandırıldığı dönemler olmuştur. Bazı Yahudi düşünürler, farklı dönemlerde apikoros terimiyle nitelendirilmiştir. Bunlara örnek olarak; Elişa ben Abuya ${ }^{33}$ (MS. 2. yy.), Hivi el-Belhi' ${ }^{34}$ (MS. 9. yy.) ve Baruh Spinoza ${ }^{35}$ (ö. 1677) verilebilir. ${ }^{36}$

Yahudilerin Epikür ve Epikürcü ekolle karşılaşmaları Helenistik dönemin (MÖ. 322-MÖ. 30) başlarına denk gelmektedir. Mesela Vaiz Kitabı, Helenistik dönemde kaleme alınmış ve kitabın yazarının dönemin popüler akımlarından olan Epikürcülükten etkilendiği birçok araştırmacı tarafından iddia edilmiştir. ${ }^{37}$ Vaiz Kitabı'nda Yahudi inanç esaslarına aykırı görülen yaklaşımlar söz konusudur. Bu kitaba göre dünya boş ve değersiz, ölüm ise yok oluş, bir tür hiçliktir. Kâinat kendi kendine işleyen bir düzene sahiptir. Dolayısıyla dünya hayatının kaygı, endişe ve yükümlülükler yerine eğlence ve mutlulukla geçirilmesi gerektiği vurgulanmaktadır. Vaiz Kitabı yazarının, Epikürcülükten etkilenmesi ve bunu metne yansıtması kitabın güvenilirliğine gölge düşürmüştür. Tanah'taki Eyüp Kitabı da aynı dönemde kaleme alınmıştır. Aynı iddialar bu kitap için de söz konusu olmuş ve yazarın eserde öne çıkardığg görüşlerin Epikürcü ekole dayandığı iddia edilmiştir. ${ }^{38}$

Epikür, ilahi kaderi inkâr etmiştir. Yunan kaynaklarında da bu hususa kanıt mahiyetinde anlatımlar mevcuttur. ${ }^{39}$ Öte yandan hahamlara göre Epikürcülük, ateizmden daha kötü ve daha tehlikelidir. Çünkü Epikürcü

Ayrıntılı bilgi için bkz. Alon Goshen, Gottstein, The Sinner and Amnesiac - The Rabbinic Invention of Elisha ben Abuya and Eleazar ben Arach (California: Stanford University Press, 2000).

34 Ayrıntılı bilgi için bkz. Muhammed Ali, Bağır, "Ortaçağda Bir Yahudi Heretik: Hîvî el-Belhî ve Tanah Eleştirisi”, İsrailiyat, 1 (Kış 2017): 9-24.

35 Ayrıntılı bilgi için bkz. Benedict de Spinoza, Teolojik-Politik İnceleme, çev. Musa Kazım Arıcan (Ankara: TDV, 2011); Steven Nadler, Spinoza: Bir Yaşam, çev. Anıl Duman \& Murat Başekim (İstanbul: İletişim Yayınları, 2018); Musa Kazım Arıcan, Spinoza'nın Tanrı Anlayışı (Ankara: Hece Yayınları, 2015).

36 Malkin, Epicurus \& Apikorsim, 58, 61-62, 82, 88.

37 Vaiz Kitabı, Tanah'taki diğer kitaplardan farklı bir dil ve Tanrı anlayışına sahiptir.

38 Malkin, Epicurus \& Apikorsim, 43-49.

39 Yosef Geiger, “Le-Toldot ha-Munah “Apikoros”, Tarbiz 42 (1973): 499-500. 
felsefeye göre tanrılar, hiç kimseyi ve hiçbir şeyi önemsemezler. Bu nedenle insanlara ilahi bir ceza veya ödül verilmeyecektir. ${ }^{40}$

Yahudi din adamları, Epikür'ün görüşlerinin yaygınlık kazanmasıyla birlikte Yahudilerin de dinî vecibe ve inançlarını sorgular hale geldiklerine şahit olmuşlardır. Dolayısıyla, Yahudi inançlarına taban tabana zıt düşen bu felsefi ekol bir tehdit olarak algılanmış ve yasaklanmıştır. ${ }^{41}$ Ancak apılan tüm eleştirilere rağmen Epikürcü görüşlerin Yahudiler arasında yayılmaya devam etmesi üzerine, Yahudi âlim Eleazar ben Arah, dindar Yahudileri bu itikâdî tehdide karşı uyarmak ve apikorosların sözlü saldırılarına karşı her zaman hazır olunması gerektiğini vurgulamak maksadıyla "Apikoroslara Nasıl Cevap Vereceğini Bil”" ${ }^{22}$ başlıklı bir savunma metni hazırlamıştır. ${ }^{43}$

Yahudi dinî literatürü incelendiğinde İbn Meymun'un Delâletu'lHâirîn adlı eserinde Epikür'e dair ayrıntılı bilgi verdiği görülmektedir. Eserde apikoros kavramı üç kez geçmektedir. İbn Meymun, Epikür'ün görüşünü aktarmış ve bu akımın Yahudilik üzerindeki etkisini şu sözlerle ifade etmiştir:

Birinci Görüş (Epikür'ün Görüşü): Varlıktaki hiçbir şeyde inayet olmadığını zannedenlerin görüşüdür. Bu görüşe göre gerek sema gerekse de diğer şeylerde görülen inayet (düzen) tesadüf eseri (bi'l-ittifak) ve rastgele olmaktadır. Dolayısıyla âlemde bir düzen verici, müdebbir ve şeylere inayet veren bir varlık bulunmamaktadır. Bu görüş Epikür'ün görüşüdür. Yine Epikür atomlar hakkında da bunu söylemekte ve onların tesadüf eseri bir araya geldiklerini ve şeylerin de onlardan yine tesadüf eseri oluştuğu görüşündedir. İsrailoğullarının içerisindeki kâfirler de bu görüşü benimsemişlerdir. $\mathrm{Bu}$ kimseler hakkında Tevrat'ta "Tanrı'yı kabul etmeyerek 'O yoktur' dediler" 44 denilmiştir. ${ }^{45}$

$40 \quad$ Saul Lieberman, "How Much Greek in Jewish Palestine?", Essays in Greco-Roman and Related Talmudic Literature (New York: Ktav Publishing House, 1977), 332.

41 Malkin, Epicurus \& Apikorsim, 37, 40.

42 Mişna, Avot, 2:14. Tevrat'ı küçümseyip alay konusu yapan kişiye cevap verebilmek için her bir Yahudi'nin Tevrat'ı çok iyi biliyor olması gerekir. Eğer o kimse Tevrat'ı tam anlamıyla bilmiyorsa apikorosla tartışmamalıdır. Çünkü Yahudi, cahilliği nedeniyle apikorosun düşüncelerinden etkilenebilir ve bu tartışma onun imanını zayıflatabilir. Bkz. Rav Naftali Haleva, Pirke Avot (İstanbul: Gözlem Yayıncılık, 2004), 52.

43 Juda Bergmann, "Epicurus", The Universal Jewish Encyclopedia (New York: Universal Jewish Encyclopedia Co. Inc., 1948), 4: 136.

44 Yeremya 5:12.

45 Musa b. Meymun, Delâletu'l-Hâirîn, çev. Özcan Akdağ \& Osman Bayder (Kayseri: Kimlik Yayınları, 2019) 3: 17. 
Terimin etimolojisine ilişkin farklı iddialar da söz konusudur. Apikoros sözcüğünün literal kökeninin Epikür'e dayandığı fikri baskınken Yahudi din adamları, kelimenin kökenini kendi dil ve kültürlerine dayandırmaya çalışmışlardır. ${ }^{46} \mathrm{Bu}$ doğrultuda onlar, terimin "özgür bırakma ${ }^{47}$ ve sahipsiz, ${ }^{48}$ anlamlarındaki Aramice (hefker) sözcüğünden türediği fikrini savunmuşlardır. ${ }^{49}$ Hefker kelimesinin Yahudi literatüründe birçok kullanımı vardır. Ancak kelimenin apikoros bağlamı esas alındığında başvurulan anlamı "sahipsiz"dir. Hefker sözcüğünü sahipsiz anlamında kullananlardan biri de İbn Meymun'dur. ${ }^{50}$ Kelimenin "sahipsiz" anlamı göz önüne alındığında apikoros, hefkerdir. ${ }^{51}$ Burada kastedilen, dinî esaslara bağlanmayan kişinin yalnız ve kimsesiz kalacağıdır. Terimin kökenini hefkerle ilişkilendiren bir diğer din adamı ise İtalyan haham Bartenura'dır (ö. 1515). Ona göre apikoros; Tevrat'ı küçük gören, ona hefker (sahipsiz) muamelesi yapan kişidir. Bu sapkın kişi, saygısız davranışının neticesinde bir kötülüğe maruz kalma veya bir musibetle karşılaşma kaygısı taşımayarak hefker konumuna gelmektedir. ${ }^{52}$ Apikoros teriminin etimolojik kökenini hefker'e bağlayan yaklaşıma göre, apikorosların dünyanın sahipsiz olduğunu öne sürüp dinî hukuk çerçevesinde yaşamayarak sahipsiz/başıboş kalmaları arasında bir bağlantı olduğu söylenebilir.

Terimin kökeni bağlamında başvurulan bir diğer sözcük ise Aramice (afkiruta) kelimesidir. Apikoros "saygısızlık" anlamındaki afkiruta kelimesiyle de benzerlik göstermektedir. Bu bağlamda kelimenin, "Sözlü Tevrat'a, onun âlimlerine ve talebelerine saygısızlık yapan" manası esas alınmıştır. ${ }^{53}$ Talmud'daki bilgiye göre apikoros, herhangi bir Tevrat âlimini küçük gören ya da bir Tevrat âliminin önünde arkadaşını küçümseyen yahut onunla alay eden kişidir. Tevrat âlimine saygısızlıktan kasıt, apikorosun Tevrat'ı, uygun olmayan bir biçimde, kafasına göre

46 Louis Isaac Rabinowitz, “Apikoros”, Encyclopedia Judaica, 2: 256; Grossberg, Heresy and the Formation of the Rabbinic Community, 144.

47 Babil Talmudu, Sanhedrin, 99b.

48 Birnbaum, "Hefker", 169.

49 Rabbi Yona Gerondi şerhi, Mişna, Avot, 2:14; Jastrow, "Hefker”, 362; Rabinowitz, “Apikoros", 256.

50 Bu bağlamda o, şöyle demiştir: "Çöllerde, nehirlerde ve akarsularda bulunan her şey hefker (sahipsiz)dir.” Mişne Tora, Hilhot Zehiya u-Matana, 1:1. Hefker sözcüğü İslam hukukundaki lukata kavramiyla benzerlik göstermektedir. Lukata, "mâlikinin iradesi dışında kaybolmuş ve bir başkası tarafından bulunmuş sahibi bilinmeyen mal" anlamında kullanılır. Ayrıntılı bilgi için bkz. Saffet Köse, "Lukata”, Türkiye Diyanet Vakfi İslam Ansiklopedisi (Ankara: TDV Yayınları, 2003), 27: 223-225.

51 Rabbi Yona Gerondi şerhi, Mişna, Avot, 2:14.

52 Bartenura şerhi, Mişna, Avot, 2:14.

53 İbn Meymun, Şerhu'l-Mişna, Sanhedrin, 10:1; “Apikoros”, Entsiklopediya Talmudit (Kudüs: Talmudic Encyclopedia Publ. Ltd., 2000) 2: 136. 
yorumlamasıdır. ${ }^{54}$ Rabbi Yona Gerondi'ye göre, "ister din adamlarının önünde isterse gıyaplarında onlara saygısızlık eden kişi” apikorostur. ${ }^{55}$ Kudüs Talmudu'ndaki tanıma göre, "o sofer", 56 "o hahamlar" diyen kişi apikorostur. ${ }^{57}$ Bunun nedeni ise bu tür sözcüklerin, ilgili şahsın ismini bir saygı unvanı kullanmadan "falanca kişi” der gibi bir anlam taşımasıdır. Bu da hahamlara ve soferlere yönelik bir hakaret ifadesi sayılmaktadır. Bu bilgilerden yola çıkarak apikorosun yanlış bir Tanrı inancı veya hatalı bir ahiret algısından ziyade, soferler ve din adamlarına yaklaşımındaki saygısızlık sebebiyle sapkın ilan edildiği söylenebilir..$^{58}$ Talebenin hocasından ismiyle bahsetmesinin yanlışlığına dair bir başka ifade ise Babil Talmudu'nda yer almaktadır. Rav Nahman; “(Apikoros), hocasından ismiyle bahseden kimsedir" 59 demiştir. Burada, kişinin hocasının adını, unvanı olmadan, sanki onun arkadaşımışçasına zikretmesinin apikorosluğun bir göstergesi olduğuna işaret edilmektedir.

Apikoros kategorisine giren bir diğer grup ise, "Hahamların bize ne yararı var?" demek suretiyle din adamlarının sadece kendi çıkarları için Tevrat çalıştıklarını, onların sarf ettikleri çaba ve yaptıkları çalışmaların faydasız ve boş bir uğraş olduğunu söyleyenlerdir. Bir hahamın huzurunda oturarak ona hak ettiği saygıyı göstermeyen kimse de apikoros olarak anılır. ${ }^{60}$ Yine bu çerçevede İbn Meymun'un yaptı̆̆ 1 açılklamaya göre apikoros terimi, şeriat kurallarını ve din adamlarını aşağılama ve hafife alma (istihfâf) anlamını haiz bir kelimedir. ${ }^{61}$

Yahudi din adamlarına yapılan saygısızlığın itikâdî bir sapkınlık sayılmasının nedenini anlamak için Yahudilikte hahamların konumunu bilmek gerekir. ${ }^{62}$ Talmud'da dünyanın varlığının hahamların Tevrat çalışmalarına bağlı olduğu yönündeki açık ifade, din adamlarının önemine

54 Babil Talmudu, Sanhedrin, 99b. Aslında bir kimsenin Tevrat âliminin önünde arkadaşını küçümsemesi veya onunla alay etmesi dolaylı olarak Tevrat âlimine saygısızlık etmek anlamına gelir. Tevrat âlimine saygısızlık etmek ise Tevrat'a saygısızlık etmektir. Afkiruta kelimesinin "saygısızlık" anlamında kullanıldığı başka bölümler de vardır. Bkz. Babil Talmudu, Moed Katan 16a, Eruvin 63a.

55 Rabbi Yona Gerondi, Şa'arey Teşuva, 3:62.

56 Tevrat'ı tefsir eden, dinî yasaları ve ahlak kurallarını insanlara öğreten Yahudi bilginlere sofer (çoğulu soferim) adı verilmiştir. Soferler MÖ. 5. yy. ile MÖ. 200 yılları arasında Yahudi tarihinde aktif rol almışlardır. İlk sofer ise Ezra'dır.

57 Kudüs Talmudu, Sanhedrin, 27d.

58 Grossberg, Heresy and the Formation of the Rabbinic Community, 153.

59 Babil Talmudu, Sanhedrin, 100a.

6o Babil Talmudu, Sanhedrin, 99b.

61 İbn Meymun, Şerhu'l-Mişna, Sanhedrin, 10:1.

62 Yahudi din adamlarıyla ilgili bilgi için bkz. Yasin Meral, Yahudi Kaynakları Işığında Yahudilik (İstanbul: MilelNihal Yayınları, 2021), 219-224. 
örnek olarak verilebilir. ${ }^{63}$ Yahudi din adamları kurumsal, dinî ve sosyal açıdan önemli fonksiyonlara sahiptirler. ${ }^{64}$

Babil Talmudu ve Kudüs Talmudu'nda apikoros için değişik tanımlar mevcuttur. Ancak ikisinin ortak noktası, bahsi geçen terimin Yahudi din adamlarına ve onların sözlerine saygısızlık edenler için kullanılmasıdır. Bu bilgiler ışığında, apikoros sözcüğünün önce sadece belirli bir grubu ifade ettiği, ancak zamanla cins isme dönüştüğü ve böylece İbraniceye aktarıldığı söylenebilir. ${ }^{65}$ Apikorosun Yunan filozof Epikür'den türeyen bir terim olduğunu iddia edenlerin yanı sıra terime Aramice ve İbranice bir köken bulmaya çalışanlar da olmuştur. Ancak genel kanaat terimin Epikür'le bağlantılı olduğu yönündedir.

Yahudilikte itikâdî sapkınlık için kullanılan terimlerden bazıları İslam literatüründe yer alan kavramlarla örtüşmektedir. Bu kavramlardan biri de apikorostur. İçerik açısından ele aldığımızda apikoros teriminin kâfir ${ }^{66}$ ve mülhid ${ }^{67}$ kavramlarını karşıladığı söylenebilir.

\section{2) Apikoros Kavramının Yahudi Dinî Literatüründe Kullanımı}

Rabbani literatürde apikoros terimi, ilk kez Mişna'da kullanılmıştır. Mişna'da iki yerde geçen apikoros, Sanhedrin bölümünde gelecek dünyadan nasibi olmayanlar arasında zikredilmiş, ${ }^{68}$ Avot bölümünde ise "Tevrat çalışmasında gayretli ol ve apikorosa nasıl cevap vereceğini bil"69 denilerek Yahudiler apikoroslara karşı uyarılmıştır.

Kavrama yer verilen bir diğer kaynak Tosefta'dır. Burada ise apikorosların gelecek dünyadaki akıbetleriyle alakalı olarak şöyle bir bilgi paylaşılmıştır:

\footnotetext{
63 Babil Talmudu, Sanhedrin, 99b.

64 Yitzhak Brand, Mi Hu Hiloni? (Kudüs: The Israel Democracy Institute, 2012), 89.

65 Deutsch, “Apikoros", 2: 665.

66 “Sözlükte ‘örtmek, gizlemek; nankörlük etmek' gibi manalara gelen küfr, terim olarak genellikle 'Allah'tan alıp din adına tebliğ ettiği hususlarda peygamberi tasdik etmemek, ona inanmamak' diye tanımlanır. Küfrü benimseyene 'fitrî yeteneğini köreltip örten' anlamında kâfir denir." Mustafa Sinanoğlu, "Küfür”, Türkiye Diyanet Vakfi İslam Ansiklopedisi (Ankara: TDV Yayınları, 2002), 26: 533-534.

67 "Sözlükte 'meyledip yönelmek, gerçekten sapmak, emredileni yerine getirmemek, kuşku duymak, mücadele ve münakaşa etmek' gibi anlamlara gelen ilhâd, kelâm terimi olarak 'Allah'ın varlığı veya birliğini, dinin temel hükümlerini inkâr etmek, bunlar hakkında kuşku beslemek veya uyandırmak, dinî kuralları hafife almak' manasında kullanılır. İlhâda sapan kimseye mülhid denir." Sinanoğlu, “ílhad”, Türkiye Diyanet Vakfi İslam Ansiklopedisi (İstanbul: TDV Yayınları, 2000) 22:90.

68 Mişna, Sanhedrin, 10:1.

69 Mişna, Avot, 2:14.
} 
Minler, meşumadlar, muhbirler, apikoroslar, Tevrat'ı inkâr edenler, toplumun kurallarına uymayanlar, öldükten sonra dirilmeyi reddedenler, günah işleyen herkes ve halkın günah işlemesine sebep olan herkes... Cehennem onların önünde kilitlenir ve nesilden nesile yargılanırlar. ${ }^{70}$

Apikorosa dair bilgi verilen bir başka kaynak ise Talmud'dur. Mişna'da apikorosun tanımı yer almasa da Talmud'da apikorosun kim olduğuna dair bilgi verilmiştir. Burada apikoros, bir Tevrat âlimini veya bir Tevrat âlimi huzurunda arkadaşını küçümseyen kişi olarak tanıtılmaktadır. Ayrıca etimoloji bölümünde de aktardığımız üzere, hahamların kendi çıkarları için Tevrat öğrendiklerini, onların Yahudi cemaatine bir faydalarının olmadığını söyleyen kimse de apikoros olarak isimlendirilmiştir. ${ }^{71}$ Başka bir bölümde aktarılan bilgiye göre ise hocalarından ismiyle bahseden kişi de apikorostur. ${ }^{72} \mathrm{Bu}$ ifadenin bir benzeri Kudüs Talmudu'nda yer almaktadır. Burada, apikorosun din adamlarına unvanlarını zikretmeksizin saygısızca hitap eden yahut giyaplarında onlardan bahseden kişi olduğu bildirilmiştir. ${ }^{73}$ Öte yandan, apikorosların günahkâr oldukları, tıpkı diğer günahkârlar gibi cehennemde cezalandırılacakları ve nesiller boyunca orada kalmaya devam edecekleri açıkça ifade edilmiştir. ${ }^{74}$

Yahudi âlimler de eserlerinde apikoros terimine yer vermişlerdir. $\mathrm{Bu}$ bağlamda öne çıkan isim İbn Meymun'dur. Yahudi tarihinde iman esaslarını sistematik olarak hazırlayan ilk Yahudi düşünür odur. ${ }^{75} \mathrm{O}$, oluşturduğu bu listeyi Şerhu'l-Mişna ${ }^{76}$ adlı eserinde açıklamış ve her bir Yahudinin on üç maddelik bu esaslara inanması ve uyması gerektiğini vurgulamıştır. İbn Meymun'a göre, bu esaslardan bir veya birkaçını reddeden kişi Yahudi topluluğundan çıkar. Bu eserde verilen bilgiye göre inkârcilar min, apikoros ve kotsets be-neti'ot şeklinde isimlendirilirler. ${ }^{77}$

70 Tosefta, Sanhedrin, 13:5.

${ }^{71}$ Babil Talmudu, Sanhedrin, 99b.

72 Babil Talmudu, Sanhedrin, 100a.

73 Kudüs Talmudu, Sanhedrin, 27d.

74 Babil Talmudu, Roş ha-Şana, 17a.

75 Menachem Kellner, Dogma in Medieval Jewish Thought (New York: Oxford University Press, 1986), 200. İskenderiyeli Philo (ö. 50) ve Saadya Gaon (ö. 942) İbn Meymun'dan önce iman esaslarıyla ilgili çalışmalar yapmışlar, fakat bunları listeleyen ilk Yahudi İbn Meymun olmuştur. Yahudi iman esasları listesi için bkz. Yasin Meral, "İbn Meymun'a Göre Yahudilik'te İman Esasları”, Ankara Üniversitesi İlahiyat Fakültesi Dergisi, 52/2 (2011): 243-266; Ravza Aydın, "Yahudi İman Esasları", Sakarya Üniversitesi İlahiyat Fakültesi Dergisi, 14/25 (2012/1): 189-210.

76 Eser, Yahudiler arasında Kitabu's-Sirac ismiyle tanınmaktadır. Ancak İbn Meymun hiçbir zaman böyle bir isim kullanmamış, eserini Şerhu'l-Mişna şeklinde isimlendirmiştir.

77 İbn Meymun, Şerhu'l-Mişna, Sanhedrin, 10:1. 
Burada apikoros, şeriatı ve hahamları hafife alan kimse olarak tanıtılmıştır. İbn Meymun, aynı bölümde, apikorosu şu şekilde tanımlamıştır:

Apikoros ifadesi Süryanice ${ }^{78}$ bir kelimedir. Anlam olarak ise şeriatı ve onun taşıyıcıları olan hahamları küçümseyen ve onlarla alay eden kimseleri ifade eder. Bu nedenle bu isim; dinin kâidelerine inanmayan, hahamlar ve din bilginleriyle dalga geçen veya Tevrat öğreticileriyle alay edenler için kullanılır. ${ }^{79}$

İbn Meymun, Talmud ve Mişna'da bulunan apikoros tanımlarını bir araya getirmiş ve eklemeler yapmıştır. Mesela yukarıda verilen ifadede "dinin kâidelerine inanmayan" kişiyi de apikoros addederek terimin kapsamını genişletmiş ve özgün açıklamasını ortaya koymuştur.

Şerhu'l-Mişna'daki tanımına ek olarak İbn Meymun, Mişne Tora adlı eserinde daha ayrıntılı ve sistematik bir tanım yapmıştır. Ona göre üç tür insan apikorostur:

- Nübüvvetin varlığını inkâr eden ve "Tanrı tarafından insanların kalbine aktarılan bilgi (vahiy) yoktur." diyenler

- Musa'nın peygamberliğini reddedenler

- "Yaratıcı, insanların eylemlerinden haberdar değildir." diyenler ${ }^{80}$

İbn Meymun'un Mişne Tora'sında apikoros teriminin kullanım alanları iki grupta ele alınabilir. Bu doğrultuda terimin kâfir ${ }^{81}$ manasında kullanıldığı bölümlerin yanı sıra cemaatten ayrılan, muhbir ve Yahudileri zor durumda bırakan ${ }^{82}$ anlamında kullanıldığı kısımlar da bulunmaktadır. İbn Meymun'un ifadesine göre apikoros, dinin temel inançları hususunda günah işleyen kişidir. Talmud âlimleri ise, dinî uygulamalar noktasında günah işleyen kişiyi apikoros kategorisine almışlardır. ${ }^{83}$ Riskin'e göre İbn Meymun, apikorosu tanımlarken doğrudan Epikür'le ilişkilendirmese de

78 İbn Meymun, Süryanice kelimesiyle Aramiceyi kastetmektedir.

79 Lafzatü apikoros hiye lafzatün Süryaniyyetün mâ'nâhâ el-istihfâfve’t-tehâvün bi’ş-şeriati ev bi-hameleti'ş-şeria. İbn Meymun, Şerhu'l-Mişna, Sanhedrin, 10:1.

80 İbn Meymun, Mişne Tora, Hilhot Teşuva, 3:8. İbn Meymun, bu tanıma benzer başka bir tanım daha yapmaktadır: "Apikoros, Tevrat'ı ve nübüvveti inkâr eden Yahudidir." İbn Meymun, Mişne Tora, Hilhot Rotseah u-Şemirat Nefeş, 4:10. İbn Meymun, Mişne Tora, Hilhot Şehita, 4:14; Hilhot Rotseah u-Şemirat Nefeş, 4:10; Hilhot Edut, 11:10; Hilhot Mamrim, 3:1. İbn Meymun, Mişne Tora, Hilhot Avel 1:10; Hilhot Teşuva, 3:11; Hilhot Avodat Kohavim 10:1.

83 Bkz. Babil Talmudu, Sanhedrin, 99b, $100 a$. 
zihninde Epikür vardır. ${ }^{84}$ İbn Meymun'un apikoros tanımını savunan Katalonyalı haham Menahem Meiri (ö. 1306), bu tanıma bir şerh düşmüştür. O, Talmud'un apikoros tanımın1 ${ }^{85}$ esas alarak, bir âlimi küçümseyen kimsenin onun sözlerini ve bilgeliğini de küçümseyeceğini ve nihayetinde Yahudilerin bütün inanç esaslarını inkâr edeceğini vurgulamıştır. ${ }^{86}$

Apikoroslar dünyada Yahudi kabul edilseler bile ahirette cezalandırılacaklardır. Yahudi milletinden olsalar dahi gelecek dünyadan nasiplerinin olamayacağı ise Mişne Tora'da şöyle bildirilmiştir: "Saydığımız yirmi dört kişinin her biri (apikoroslar da dâhil), Yahudi bile olsalar gelecek dünyadan nasipleri yoktur." 87

Mişna'yı şerh eden Yahudi âlimler de apikorosu tanımlamışlardır. Rabbi Yona Gerondi'ye göre, apikoros “Sözlü Tevrat'ı inkâr eden ve hayatını halahaya göre düzenlemeyen kimsedir." ${ }^{88}$ Sanhedrin bölümünde, günahları nedeniyle apikoroslar gelecek dünyadan nasibi olmayacak kişiler listesine dâhil edilmiştir. ${ }^{89}$ Bir iddiaya göre, buradaki apikoros sözcüğüyle asıl kastedilen ataların geleneklerini ve dirilişi ${ }^{90}$ inkâr eden Sadukilerdir. ${ }^{91}$ Sadukiler için apikoros denilerek pejoratif bir gönderme yapmak amaçlanmıştır. Terim, MS. 1. yüzyılda bu bağlamda kullanılmıştır. ${ }^{92} \mathrm{Bu}$ bilgi ışığında apikoros teriminin başka bir grubu daha belirtmek için kullanıldığı görülmektedir. ${ }^{93}$

Yahudi dinî literatüründe apikoros kavramı çeşitli boyutlarıyla ele alınmıştır. Sapkın addedilen bu kimselerin sayısının artması ve Yahudi cemaati için bir tehdit olarak görülmeleri sebebiyle literatürde apikorosların tanımı, düşünce sistemleri, onlarla nasıl mücadele edileceği

84 Shlomo Riskin, "Orthodoxy and Her Alleged Heretics", Tradition: A Journal of Orthodox Jewish Thought 15/4 (İlkbahar 1976): 37.

85 Babil Talmudu, Sanhedrin, 99b.

86 Menahem Meiri, Bet ha-Behira, Sanhedrin, 99b.

87 İbn Meymun, Mişne Tora, Hilhot Teşuva, 3:14.

88 Rabbi Yona Gerondi şerhi, Mişna, Avot, 2:14.

89 Mişna, Sanhedrin, 10:1.

9o Yahudilikte ahiret inancı için bkz. İsmail Taşpınar, Yahudilik'te Ahiret İnancı (İstanbul: İFAV, 2015).

91 Sadukiler, II. Mabed'in yıkımına kadar (MS. 70) varlıklarını sürdürmüştür. Sadece Yazılı Tevrat'ı kabul ederek Sözlü Tevrat'ı ve dolayısıyla dirilişi inkâr etmişlerdir. Sadukilerin goylar gibi (saduki ke-nohri) kabul edilip edilmemesi durumu Yahudi din adamları tarafından tartışılmıştır. Öte yandan, günahkâr olsalar da hâlâ "Yahudi" oldukları ve tövbe (teşuva) kapısının onlar için açık olduğu da söylenmiştir. Bkz. Sacha Stern, Jewish Identity in Early Rabbinic Writings (Leiden: E. J. Brill, 1994), 112113.

92 Grossberg, Heresy and the Formation of the Rabbinic Community, 148. Ayrıntılı bilgi için bkz. Daniel Boyarin, Border Lines: The Partition of Judaeo-Christianity (Philadelphia: University of Pennsylvania Press, 2004), 58.

93 Grossberg, Heresy and the Formation of the Rabbinic Community, 150. 
ve Tanrı'nın ahirette onları nasıl cezalandıracağı gibi birçok hususa yer verilmiştir. Bu bağlamda, apikorosların Yahudi inanç esaslarına aykırı düşüncelere sahip sapkın bir grup olduğu şeklindeki söylemin yanı sıra Tevrat'a ve Tevrat âlimlerine yaptıkları saygısızlığa da vurgu yapılmıştır.

\section{3) Yahudilikte Apikorosların Statüsü}

Apikorosların heretik kabul edilmeleri Yahudi hukukunda bazı yaptırımlara maruz kalmalarına neden olmuştur. İnsanlar farklı sebeplerle Yahudiliğin inanç esaslarından birini veya birkaçını inkâr edebilirler. Bu bağlamda kişi, özgürce hareket etme isteğiyle, Yahudi toplumunu yok etme düşüncesiyle veya entelektüel sebeplerle inkârcı olabilir. Dolayısıyla kişinin apikoros olma nedenleri göz önünde bulundurulmalı ve buna göre bir ayrım yapılmalıdır. Öte yandan bir apikorosu yargılamadan önce onun özgür iradesiyle mi yoksa baskıyla ${ }^{94} \mathrm{ml}$ apikoros olduğunun bilinmesi şarttır. Entelektüel sebeplerle veya baskı sonucu geleneksel Yahudi düşüncesine aykırı fikirler besleyenlerin tövbe (teşuva) ${ }^{95}$ etmeleri sağlanabilir. ${ }^{96}$

Apikoroslar tek bir gruptan ibaret değildir. Bu kimseler sahip oldukları özelliklere göre alt gruplara ayrılabilmektedir. Bu noktada goy apikoros ve Yahudi apikoros ayrımı örnek verilebilir. Goy apikoroslar dinî meseleler hakkında Yahudilere soru yönelttiklerinde soruları cevaplanmalıdır. Ancak Yahudi apikoroslarla tartışmaya girmek uygun değildir. Zira goy apikorosun hakikatten sapma nedeni bilgi eksikliğidir. Ancak Yahudi apikoros, bilgili olduğu halde kasten sapkınlığı tercih etmiştir. ${ }^{97}$ Mişna'da "Apikoroslara Nasıl Cevap Vereceğini Bil"98 ihtarında kastedilen apikoros, goy apikorostur. ${ }^{99}$

Yahudi apikoroslar, her ne kadar itikâdî meselelerde yanlışa düşseler de Yahudi olmaya devam edebilirler. Talmud'da yer alan şu ifade bu fikri desteklemektedir: "Yahudi ${ }^{100}$ günah işlese de yine Yahudidir." ${ }^{101}$ Bu teze örnek teşkil edecek bir rivayet aktarılmıştır. Buna göre, Avrupa'da yaşayan

94 İradesi dışında günah işlemeye zorlanan kimselere anusim adı verilmektedir. Ayrıntılı bilgi için bkz. Haim Hillel Ben-Sasson, "Anusim”, Encyclopedia Judaica, 2: 251-254.

95 Yahudilikte tövbe konusuyla ilgili bkz. Mehmet Katar, Yahudilik, Hiristiyanlık ve İslam'da Tövbe (Ankara: Eskiyeni, 2017); Bektaş, Yahudilikte İtikâdî Sapkınlıklar ve Cezaları, 109-119.

96 Riskin, "Orthodoxy and Her Alleged Heretics", 39-41.

97 İbn Meymun, Şerhu'l-Mişna, Avot, 2:14.

98 Mişna, Avot, 2:14.

99 Babil Talmudu, Sanhedrin, 38b.

100 İbranice metinde "İsrail" sözcüğü yer almaktadır. Bu ifadeyle kastedilen Yahudilerdir.

101 Babil Talmudu, Sanhedrin, 44a. 
bir Yahudi, Şabat akşamları havdala ${ }^{102}$ sonrası itikâdî sapkınlığını dışa vuran sorular sorarak hahamı kızdırmıştır. Bunun üzerine haham, "Eğer böyle düşünüyorsan neden her Şabat buraya geliyorsun" dediğinde, o kimsenin cevabı "Ben bir apikorosum, goy değilim" şeklinde olmuştur. ${ }^{103} \mathrm{Bu}$ olay, kişilerin Yahudilikten tamamen kopmadan apikoros olabileceklerini göstermesi açısından önem arz etmektedir.

Halahada apikoroslara nasıl davranılması gerektiğine dair bazı ifadeler bulunmakta ve bu kurallar apikorosları Yahudi toplumunda dinî, hukuki ve sosyal açıdan çeşitli olumsuz yaklaşım ve yaptırımlara maruz bırakmaktadır. Mesela onların şahitlikleri kabul edilmez, söyledikleri sözlere hep şüpheyle yaklaşılır ve doğruluğuna inanılmaz. Bir Yahudi bir apikorosun herhangi bir eşyasını bulursa ona iade etmemelidir. ${ }^{104}$ Mişne Tora'da Tevrat'a ve Musa'nın peygamberliğine inanmayan apikorosun goy hükmünde olacağı belirtilmektedir. Dolayısıyla onun kestiği hayvan da leş sayllır. ${ }^{105}$

Bilindiği üzere Yahudilikte kutsal metinler ve şerhlerinin yakılması veya yok edilmesi kesinlikle yasaktır. ${ }^{106}$ Fakat Tanrı'nın ismi yazılı olsa bile Yahudi bir apikorosun yazdığı Tevrat tomarı yakılmalıdır. Zira apikoros, Tanrı'nın ismini yazarken onun kutsallığını hiçe sayarak normal bir isim yazar gibi yazmıştır. Diğer yandan bir goy tarafından yazılan kutsal metin yakılmaz, toprağa gömülür. ${ }^{107} \mathrm{Bu}$ bilgi ışığında, apikorosların goylarla mukayese edildiğinde dinî açıdan daha zararlı bir grup olarak görüldükleri söylenebilir. Ayrıca apikoroslar hükmen goylardan daha aşağı bir seviyede görülürler. Bu denli tehlikeli görülen, sapkın inançlara bağlanıp hakikatten uzaklaşan apikorosların teşuvaları (tövbe) da makbul değildir. ${ }^{108}$

Apikorosların Yahudilikteki statüleri bağlamında en dikkat çeken husus, apikorosları öldürmenin bir mitsva (emir) olmasıdır. Şartlar uygunsa alenen kılıçla öldürülmeleri, uygun ortam oluşmadıysa ölümlerine yol açacak bir plan yapılması telkin edilmektedir. ${ }^{109}$ Benzer bir muamele Talmud'da da açıkça belirtilmektedir: "Putperestlerin ve küçükbaş hayvan çobanlarının kuyuya düşmeleri halinde ne kuyudan çıkarılmalarına ne de kuyuda daha derine itilmelerine gerek yoktur. Ancak minler, muhbirler ve

102 Yeni haftaya girerken Şabat'in ve bayramın bittiğini sembolize eden bir Yahudi duasidir.

103 Riskin, "Orthodoxy and Her Alleged Heretics", 42.

104 İbn Meymun, Mişne Tora, Hilhot Gezela ve Aveda, 11:2.

105 İbn Meymun, Mişne Tora, Hilhot Şehita, 3:14.

106 İbn Meymun, Sefer ha-Mitsvot, Mitsva Lo Tease,65; Mişne Tora, Hilhot Yesodey haTora, 6:8.

107 İbn Meymun, Mişne Tora, Hilhot Yesodey ha-Tora, 6:8.

108 Yosef Karo, Kesef Mişne, Avoda Zara, 2:5.

109 İbn Meymun, Mişne Tora, Hilhot Rotseah u-Şemirat Nefeş, 4:10. 
mumarlar (dinden dönenler) daha da derine itilip yukarı çıarılmayabilirler." 110 Mişne Tora'da yer alan başka bir ifadede ise apikorosların nehre düşüp boğulduklarının görülmesi halinde onlara yardım edilmemesi gerektiği belirtilmiştir. Gerekçe olarak gösterilen husus ise apikorosların, kendi sapkın düşüncelerini aktarmak suretiyle, Yahudileri Tanrı'dan uzaklaştırmalarıdır. ${ }^{111}$

Yaşarken düşman olarak görülen apikoroslar öldüklerinde, akrabaları yas tutmaz, ${ }^{112}$ beyaz giysiler giyer ve yiyip içerler. Hatta sapkın kimseler Tanrı'nın düşmanı olarak görüldüğü için apikoros öldüğünde akrabaları kutlama bile yaparlar. Bu düşünceye kaynak olarak ise, "Ya Rab, nasıl tiksinmem senden tiksinenlerden?" 113 ifadesi gösterilmektedir. ${ }^{114}$

\section{Sonuç}

Apikoros kavramının etimolojisine dair çeşitli iddialar ortaya atılmıştır. Kelimeyi Aramice/Süryanice kökenle ilişkilendirmeye çalışan Yahudi din bilginleri olsa da kökenin Yunan filozof Epikür'le bağlantılı olduğu açıkça görülmektedir. Fakat erken dönem Yahudi dinî literatüründe apikoros ve Epikürcü ekol arasında doğrudan bir ilişkilendirme yapılmamıştır. Apikoros terimi, başta Epikür'ün görüşlerini takip eden, bir nevi Epikürcü olanları nitelemek için kullanılan özel bir isim iken, zamanla Tanrı, Tevrat ve nübüvvet hakkında olumsuz fikir sahibi olan insanları ifade eden bir cins isme dönüşmüştür.

Yahudi dinî literatüründe apikoros kavramının tanımı yapılarak çeşitli boyutları ele alınmıştır. Kelimenin kullanımı Mişna, Tosefta, Talmud ve Orta Çağ Yahudi âlimlerinin ifadelerinden yola çııılarak açlklanabilmektedir. Literatürün temel kaynaklarından olan Mişna ve Talmud, apikorosu; Tevrat âlimlerini küçük gören, onlara gereken saygıyı göstermeyen kişi olarak tanımlamıştır. Ünlü Yahudi âlim İbn Meymun, kimlerin apikoros olduğunu; Tanrı ve nübüvveti inkâr edenler, Tevrat'a sahipsiz muamelesi yapanlar ve din adamlarına saygısızca davrananlar şeklinde üç maddede listelemiştir. İbn Meymun, insanların fiillerinin Tanrı tarafından bilinmediğini iddia eden ve peygamberliği, dolayısıyla vahyi inkâr edenleri de bu listeye dâhil etmek suretiyle terimin kapsamını genişletmiştir.

\footnotetext{
11 Babil Talmudu, Avoda Zara, 26a-b. Aslında apikoros terimi bu listede yoktur, ancak Talmud şerhlerinde listeye eklenmiştir.

11 İbn Meymun, Mişne Tora, Hilhot Avodat Kohavim, 10:1.

112 İbn Meymun, Mişne Tora, Hilhot Avel, 1:10.

113 Mezmurlar, 139:21.

114 İbn Meymun, Mişne Tora, Hilhot Avel, 1:10.
} 
Yahudilikte apikoroslar, itikâdî açıdan sapkın ve tehlikeli bir grup olarak görülmüştür. Apikorosların sayısının arttığı dönemlerde Yahudi din adamları, dindar Yahudileri apikorosların inkârcı yaklaşımına karşı uyarmışlar, onlara karşı argümanlar geliştirerek Yahudilik açısından sahih kabul edilen inanç esaslarını kaleme almışlar, böylece apikoros zihniyetiyle mücadele etmeye çalışmışlardır.

Apikorosların toplum içerisindeki konumları dinî, hukuki ve sosyal açıdan çeşitli zorluklarla yüz yüze gelmelerine sebebiyet vermiştir. Hayatın birçok noktasında dışlanan apikorosların, Yahudi inanç esaslarına aykırı fikirler beslemelerinden ötürü gelecek dünyadan nasiplerinin olmayacağ 1 da vurgulanmıştır. İslam literatürüyle mukayese edildiğinde apikoros teriminin kâfir ve mülhid terimleriyle örtüştüğü söylenebilir. Ayrıca mevzubahis terim, günümüzde yaygın bir şekilde kullanılan "deist" ve "ateist" kavramlarıyla da bağlantılıdır.

\section{Teşekkür}

Yazar, makaleyi okuyarak önemli katkılarda bulunan Doç. Dr. Yasin Meral'e ve Arş. Gör. Mukadder Sipahioğlu'na teşekkür eder.

\section{Kaynakça}

Albo, Yosef. Sefer ha-'̇kkarim. Philadelphia: The Jewish Publication Society of America, 1946.

“Apikoros”. Entsiklopediya Talmudit, Kudüs: Talmudic Encyclopedia Publ. Ltd., 2000, 2: 136-137.

Arıcan, Musa Kazım. Spinoza'nıı Tanrı Anlayışı. Ankara: Hece Yayınları, 2015.

Arzi, Abraham. "Zaken Mamre". Encyclopedia Judaica, Second Edition, ed. Fred Skolnik, Detroit: Macmillan Reference, 2007, 21: 4,46.

Aydın, Fuat. Kur'an'daki Hanîf/ler ve Nasârâ Üzerine Araştırmalar. Ankara: Eskiyeni Yayınları, 2016.

Aydın, Ravza. "Yahudi İman Esasları”. Sakarya Üniversitesi İlahiyat Fakültesi Dergisi 14/25 (2012/1): 189-210.

Bağır, Muhammed Ali. "Ortaçağda Bir Yahudi Heretik: Hîvî el-Belhî ve Tanah Eleştirisi”. İsrailiyat 1 (Kış 2017): 9-24.

Bektaş, Rumeysa. Yahudilikte İtikâdî Sapkınlıklar ve Cezaları. Yüksek Lisans Tezi, Ankara: Ankara Üniversitesi, 2020.

Bergmann, Juda. “Epicurus”. The Universal Jewish Encyclopedia, New York: Universal Jewish Encyclopedia Co. Inc., 1948, 4: 136-137.

Birnbaum, Philip. Encyclopedia of Jewish Concepts. New York: Hebrew Publishing Company, 1998.

Bolay, Hayri. Felsefi Doktrinler Sözlüğü. İstanbul: Ötüken, 1981. 
Boyarin, Daniel. Border Lines: The Partition of Judaeo-Christianity. Philadelphia: University of Pennsylvania Press, 2004.

Brand, Yitzhak. Mi Hu Hiloni? Kudüs: The Israel Democracy Institute, 2012.

Cohn-Sherbok, Dan. A Concise Encyclopedia of Judaism. Londra: One World Publications, 1998.

Deutsch, Gotthard. “Apikoros”. The Jewish Encyclopedia, New York: Funk and Wagnalls, 1901, 1: 665-666.

Fischel, Henry Albert. "Epicureanism”. Encyclopedia Judaica, Second Edition, ed. Fred Skolnik, Detroit: Macmillan Reference, 2007, 6: 4,63.

Geiger, Yosef. “Le-Toldot ha-Munah 'Apikoros”. Tarbiz 42 (1973): 4,99-500.

Gottstein, Alon Goshen. The Sinner and Amnesiac - The Rabbinic Invention of Elisha ben Abuya and Eleazar ben Arach. California: Stanford University Press, 2000.

Grossberg, David M. Heresy and the Formation of the Rabbinic Community. Tübingen: Mohr Siebeck, 2017.

Güçlü, Abdülbaki v.dğr. Felsefe Sözlüğü. Ankara: Bilim ve Sanat, 2003, 472-473.

Haleva, Rav Naftali. Pirke Avot. İstanbul: Gözlem Yayıncılık, 2004.

Harman, Ömer Faruk. "Dalâlet”. Türkiye Diyanet Vakfi İslam Ansiklopedisi, Ankara: TDV Yayınları, 1993, 8: 427-428.

İbn Meymun, Musa. Delâletu'l-Hâirîn. Çev. Özcan Akdağ \& Osman Bayder, Kayseri: Kimlik Yayınları, 2019.

İbn Meymun, Musa. Mishneh Torah: Sefer Hamada. Çev. Eliyahu Touger, Kudüs: Moznaim Publishing, 2010.

İbn Meymun, Musa. Şerhu'l-Mişna. ed. Yosef Kafih, Kudüs: Mahon Mişnat haRambam, 2001.

Jastrow, Marcus. Dictionary of Targumim, Talmud and Midrashic Literature. Londra: Luzac \& Co., 1926.

Katar, Mehmet. Yahudilik, Hıristiyanlık ve İslam'da Tövbe. Ankara: Eskiyeni, 2017.

Kasher, Hannah. Al ha-Minim, ha-Apikorsim ve ha-Koferim ba-Mişnat ha-Rambam. Tel Aviv: Hakibbutz Hameuchad Publishing House, 2011.

Kellner, Menachem. Dogma in Medieval Jewish Thought. New York: Oxford University Press, 1986.

Klein, Ernest. A Comprehensive Etymological Dictionary of the Hebrew Language for Readers of English. Kudüs: Carta, 1987.

Köse, Saffet. "Lukata". Türkiye Diyanet Vakfi İslam Ansiklopedisi, Ankara: TDV Yayınlar1, 2003, 27: 223-225.

Kutsal Kitap Eski ve Yeni Antlaşma (Tevrat, Zebur, İncil). Kitabı Mukaddes Şirketi, İstanbul: Yeni Yaşam Yayınları, 2014.

Lieberman, Saul. “How Much Greek in Jewish Palestine?”. Essays in Greco-Roman and Related Talmudic Literature, New York: Ktav Publishing House, 1977, 325-343.

Malkin, Yaakov. Epicurus \& Apikorsim. Kudüs: The Library of Secular Judaism, 2007. Meral, Yasin. “İbn Meymun'a Göre Yahudilik’te İman Esasları”. Ankara Üniversitesi İlahiyat Fakültesi Dergisi 52/2 (2011): 243-266.

Meral, Yasin. Sâmirî’nin Buzağısı. 2. bs., Ankara: Ankara Okulu Yayınları, 2021.

Meral, Yasin. Yahudi Kaynakları Işığında Yahudilik. İstanbul: MilelNihal Yayınları, 2021. 
Nadler, Steven. Spinoza: Bir Yaşam. Çev. Anıl Duman \& Murat Başekim, İstanbul: İletişim Yayınları, 2018.

Rabinowitz, Louis Isaac. “Apikoros”. Encyclopedia Judaica, Second Edition, ed. Fred Skolnik Detroit: Macmillan Reference, 2007, 2: 255-256.

Riskin, Shlomo. "Orthodoxy and Her Alleged Heretics". Tradition: A Journal of Orthodox Jewish Thought 15/4, (İlkbahar 1976): 34-4,4.

Rosenthal, M. \& P. Yudin. Materyalist Felsefe Sözlüğü. Çev. Aziz Çalışlar, İstanbul: Sosyal Yayınlar, 1977.

Sasson, Haim Hillel Ben. “Anusim”. Encyclopedia Judaica, Second Edition, ed. Fred Skolnik Detroit: Macmillan Reference, 2007, 2: 251-254.

Sinanoğlu, Mustafa. “İlhad”. Türkiye Diyanet Vakfı İslam Ansiklopedisi, İstanbul: TDV Yayınları, 2000, 22: 90-92.

Sinanoğlu, Mustafa. "Küfür”. Türkiye Diyanet Vakfı İslam Ansiklopedisi, Ankara: TDV Yayınları, 2002, 26: 533-536.

Solomon, Norman. Historical Dictionary of Judaism. Londra: Rowman \& Littlefield, 2015.

Spercer, Daniel. "Min”. Encyclopedia Judaica, Second Edition, ed. Fred Skolnik Detroit: Macmillan Reference, 2007, 14: 263-264.

Spinoza, Benedict de. Teolojik-Politik İnceleme. Çev. Musa Kazım Arıcan, Ankara: TDV, 2011.

Stern, Sacha. Jewish Identity in Early Rabbinic Writings. Leiden: E. J. Brill, 1994.

Taşpınar, İsmail. Yahudilik'te Ahiret İnancı. İstanbul: İFAV, 2015.

The Mishnah. Çev. Jacob Neusner, Connecticut: Yale University Press, 1988.

The Tosefta. Çev. Jacob Neusner, Massachusetts: Hendrickson Publishers, 2013.

\section{Internet Kaynakları}

Chabad. Erişim: Ekim 2021, https://www.chabad.org.

Sefaria: A Living of Jewish Texts Online. Erişim: Eylül-Kasım 2021, https://www.sefaria.org/texts. 